\title{
PENERAPAN SISTEM APLIKASI PELAYANAN KEPEGAWAIAN (SAPK) BERBASIS ONLINE PADA BADAN KEPEGAWAIAN DAERAH KOTA PEKANBARU
}

\author{
Wasiah Sufi dan Dwi Herlinda \\ Universitas Lancang Kuning \\ Email: wasiahsufi@unilak.ac.id
}

\begin{abstract}
Abstrak
Penelitian ini dilakukan di kantor Badan Kepegawaian Daerah Pekanbaru. Berdasarkan pengamatan awal mereka dari masalah dalam menerapkan Layanan Pekerjaan Application System (SAPK Online) di Badan Kepegawaian Daerah dari Pekanbaru.in hal sumber daya manusia mampun Teknologi. Penelitian ini berfokus pada Implementasi E-Government melalui Layanan Pekerjaan Application System (SAPK Online): (1). Untuk Mengetahui bagaimana penerapan E-Government dengan menggunakan Layanan Ketenagakerjaan Aplikasi System (SAPK Online) di Badan Kepegawaian Daerah dari Pekanbaru .. (2). Untuk Mengetahui faktor penghambat pelaksanaan E-Government dengan menggunakan Layanan Pekerjaan Application System (SAPK Online) di Badan Kepegawaian Daerah dari Pekanbaru. Penelitian ini merupakan penelitian kualitatif dengan tujuan utama untuk menggambarkan dan menggambarkan secara rinci dan mendalam tentang bagaimana implementasi E-Government dalam administrasi personil melalui Dinas Pekerjaan Application System (SAPK online). Kemudian teknik analisis data yang digunakan dalam penelitian ini adalah analisis deskriptif kualitatif, yaitu teknik yang mencoba untuk menggambarkan hal-hal yang khusus untuk data yang diperoleh melalui observasi, wawancara dan dokumentasi sehingga data kualitatif, untuk dianalisis lebih lanjut untuk menjadi kesimpulan sesuai dengan indikator yang telah ditentukan oleh penulis.
\end{abstract}

Kata kunci: E-Government, SAPK Online, Administrasi Personalia.

\begin{abstract}
This research was conducted at the office of the Badan Kepegawaian Daerah of Pekanbaru. Based on their initial observations of problems in implementing Employment Service Application System (SAPK Online) at the Badan Kepegawaian Daerah of Pekanbaru.in terms of human resources mampun Technology. This study focuses on the Implementation of E-Government through Employment Service Application System (SAPK Online): (1). To Knowing how the implementation of E-Government by using the Employment Service Application System (SAPK Online) at the Badan Kepegawaian Daerah of Pekanbaru.. (2). For Knowing the factors inhibiting the implementation of E-Government by using the Employment Service Application System (SAPK Online) at the Badan Kepegawaian Daerah of Pekanbaru.. This study is a qualitative study with the primary objective to describe and depict in detail and depth about how the implementation of E-Government in personnel administration through the Employment Service Application System (SAPK Online). Then the data analysis techniques used in this research was qualitative descriptive analysis, which is a technique that tries to describe things that are special to the data obtained through observation, interviews and documentation so that a qualitative data, to be analyzed further to become a conclusions according to the indicators that have been determined by the authors.
\end{abstract}

Keywords: E-Government, SAPK Online, Personnel Administration. 


\section{PENDAHULUAN}

Perkembangan ilmu pengetahuan yang semakin tinggi menyebabkan semakin canggihnya teknologi yang digunakan oleh manusia sehingga hal ini menjadi titik awalnya teknologi menjadi semakin canggih dan mutakhir, seperti adanya internet. Penggunaan teknologi komputer yang dewasa ini semakin meluas tentunya membantu para pelaku pelayanan publik dalam mengambil keputusan didalam operasional pemerintahan baik itu kegiatan administrasi, pelayanan, maupun dalam pengolahan data kepegawaian. Pemerintah memerlukan alat bantu yang dapat diandalkan, sehingga dapat digunakan sebagai pedoman dalam melakukan kegiatan perencaaan dan pengendalian, seperti sistem informasi manajemen.

E-Government merupakan bentuk implementasi pelayanan publik yang berbasis teknologi informasi dan komunikasi, sebagai media informasi dan sarana komunikasi interaktif antara Pemerintah dengan pihak - pihak lain baik kelompok masyarakat, kalangan bisnis maupun antar sesama lembaga pemerintahan. Implementasi e-Government dalam penerapannya dimulai dari bentuk layanan yang sederhana yaitu penyediaan informasi dan data-data berbasis komputer tentang pelaksanaan penyelenggaraan pemerintahan dan pembangunan sebagai bentuk wujud keterbukaan (transparancy) dalam pelaksanaan pelayanan publik. Bentuk layanan sederhana lainnya, e-Government dapat dimanfaatkan sebagai sarana komunikasi baik intern di kalangan Satuan Kerja Perangkat Daerah (SKPD) maupun komunikasi interaktif dengan masyarakat melalui media e-mail, chatting atau teleconperence. Dalam perkembangan implementasi e-Government dikalangan pemerintahan menjadi sebuah trend diseluruh penyelenggaraan pemerintahan, hampir keseluruhan jenis aplikasi yang dipergunakan pasti melibatkan pengolahan data menjadi informasi yang selanjutnya akan dipergunakan oleh pemerintah ataupun stakeholders dalam proses pengambilan keputusan. Didalam pemerintahan hampir setiap hari para birokrat di pemerintahan harus mengambil keputusankeputusan penting yang menyangkut hajat hidup orang banyak dan keberlangsungan/keberadaan pemerintahan yang bersangkutan.

Badan Kepegawaian Daerah Kota Pekanbaru yang merupakan institusi pemerintah yang mempunyai tugas menyelenggarakan pengkajian kebijakan pengembangan sumber daya dan manajemen Pegawai Negeri Sipil, telah membuat dan mengembangkan sebuah website www.bkd.pekanbaru.go.id sebagai wujud dari kebijakan penerapan e Government. Seluruh masyarakat Pekanbaru dapat mengakses website tersebut yang membutuhkan Informasi Kepegawaian di Pekanbaru dan mekanisme pelayanan dibidang kepegawaian.

Permasalahan yang paling dianggap signifikan dalam penerapan kebijakan e-Government melalui SAPK ini adalah kemampuan sumber daya manusia dan teknologi yang terkadang masih belum mampu menangani masalah sederhana seperti gangguan pada sistem atau jaringan, jumlah Sumber Daya Manusia dalam hal ini pegawai yang bertanggung jawab terhadap program SAPK pun belum sepenuhnya memenuhi kebutuhan, dapat dilihat dari data rekapitulasi Badan Kepegawain Daerah Tahun 2015 / 2016 sesuai Pangkat dan Jabatan :

\section{METODE}

Penelitian ini dilakukan di Badan Kepegawaian Daerah Kota Pekanbaru.Penelitian ini dilaksanakan dengan pendekan Kualitatif deskriptif.Penelitian untuk mengetahui dan menganalisa tentang penerapan e-government dalam administrasi kepegawaian berbasis sistem aplikasi pelayanan kepegawaian (SAPK Online) di Badan Kepegawaian Daerah Kota Pekanbaru.Teknik pengumpulan data dilakukan dengan wawancara, observasi dan dokumentasi. 
Untuk mengetahui bagaimana Analisis Implementasi Sistem Aplikasi Pelayanan Kepegawaian berbasis e-Government Pada Kantor Badan Kepegawaian Daerah Kota Pekanbaru, penulis menggunakan metode anlisis deskriptif, yaitu suatu analisa yang berusaha memberikan gambaran terperinci Analisis Implementasi Pelayanan Kepegawaian Pada Kantor Badan Kepegawaian Daerah Kota Pekanbaru, berdasarkan kenyataan dilapangan dan hasilnya akan disajikan dalam bentuk tabel yang dilengkapi dengan menguraikan serta mengaitkan dengan teori dan memberikan keterangan yang mendukung untuk menjawab masing-masing masalah, serta memberikan interprestasi terhadap hasil yang relevan dan diambil kesimpulan serta saran.

\section{HASIL DAN PEMBAHASAN}

Penerapan Sistem Aplikasi PelayananKepegawaian(SAPK) berbsis Online PemerintahKota Pekanbaru mulai mengembangkan Sistem Aplikasi Pelayanan Kepegawaian (SAPKOnline) sejak tahun2012. Dalam pemanfaatan SAPK dikoordinasikan oleh BKN dan pelaksanaannya berpedoman pada Peraturan Kepala Badan Kepegawaian Negara Nomor 20 Tahun 2008 tentang Pedoman Pemanfaatan SAPK. Dalam perkembangannya dikeluarkanPeraturan Kepala Badan Kepegawaian NegaraNomor18 Tahun 2010 tentang Prosedur Penetapan Nomor Identitas Pegawai Negeri Sipil,Kenaikan Pangkat, Pemberhentian dan Pemberian Pensiun PegawaiNegeri Sipil,dan Perpindahan Antar Instansi Berbasis Sistem Aplikasi Pelayanan Kepegawaian On-Line (SAPK On-Line).

Selanjutnya aplikasi berbasis Web yang dijalankan secara Online ini memiliki ruang lingkup yang dijelaskan pada Peraturan Kepala (Perka) BKN No20 Tahun 2008 mengenai pedoman pemanfaatan SPAK yang menjelaskanruang lingkup SAPK yang kemudian dikeluarkan Peraturan Kepala Badan KepegawaianNegaraNomor18 Tahun 2010 tentang ProsedurPenetapan Nomor Identitas Pegawai Negeri Sipil,Kenaikan Pangkat, Pemberhentiandan Pemberian Pensiun Pegawai Negeri Sipil, dan Perpindahan Antar Instansi Berbasis Sistem Aplikasi Pelayanan Kepegawaian On-Line (SAPK On-Line). Support adalah elemen penting yang berarti hal pendukung dalam sebuah penerapan e-Government, seperti halnyadukungan penuh dari pemerintah daerah dalam melakukan implementasi sebuah kebijakan,atau berbagai aspek pendukung yang diharapkan mampu memberikan dukungan yang efektif Berbasis Internet seperti yang dijelaskan oleh Richardus Eko Indrajit dalam bukunya yang berjudul Egovernment: Konsep Pelayanan Publik Berbasis Internet dan Teknologi Informasi (2006) bahwa Elemen pertama dan paling krusial yang harus dimiliki oleh pemerintah untuk mendukung sebuah penerapan e-Government adalah sebagai berikut :

a. Kesiapan pemerintah

1. Pembuatan Situs Situs pemerintah pusat dan daerah harus secara bertahap ditingkatkan menuju ke tingkat pemanfaatan. Perlu dipertimbangkan bahwa semakin tinggi tingkatan situs tersebut,diperlukan dukungan sistem manajemen, proseskerja, dan transaksi informasi antar instansi yang semakin komplek pula. Sementara itu di Kantor Badan Kepegawaian Daerah Kota Pekanbaru sudah dibangun situs sejak tahun 2008 dengan nama www.bkd.pekanbaru.go.id.

\section{Kesiapan SDM}

Kesiapan sumber daya manusia dipemerintah yang akan menjadi"pemain utama" atau subyek di dalam inisiatif e-Government pada dasarnya adalah manusiayang bekerja dilembaga pemerintahan, sehingga tingkat kompetensi dan keahlian mereka sangat mempengaruhi performa penerapan e-Government. Semakin tinggi tingkat information technology literacy SDM dipemerintah, semakin siap merekauntuk menerapkan konsepe-Government" (Indrajit,2005:9). Namun pada kenyataannya Badan Kepegawaian Daerah Kota Pekanbaru tidak memiliki pegawai dengan tingkat kompetensi dan keahlian dibidangTeknologi Komunikasi. Selama ini Badan Kepegawaian Daerah Kota Pekanbaru tidak memiliki perangkat dan ruangan yang khusus menanganie-Government.Sementara beban ditanggung pada bidang 
data dan infomasi dan sifatnya person, untuk jaringan internet sudah terkoneksi pada masing-masing bidang yang ada diBadan Kepegawaian DaerahKota Pekanbaru.

3. Sosialisasi situs informasi baik untuk internal maupun untuk publik.

Dari hasil penelitian, sampai saat ini pelaksanaan sosialisasi situs yang dimiliki Badan Kepegawaian Daerah Kota Pekanbaru belum pernah dilaksanakan terutama untuk publik. Hal ini tidak dilaksanakan karena dengan perkembangan teknologi yang ada saat ini setiap orang dapat mengakses informasi hanya dengan mengaksesnya diinternet.

b. Alokasi Sumber Daya manusia, Keuangan, Tenaga, Waktu dan Informasi

Dalam halinipenelitifokus membahas mengenai ketersediaan sumber daya manusia, finansial, tenaga, waktu dan informasi didalam pelaksanaan sitem Aplikasi Pelayanan Kepegawaian (SAPK online) oleh Badan Kepegawaian DaerahKota Pekanbaru. Setelah melakukan penelitian dan melaksanakan wawancara dengan pegawai Badan Kepegawaian Daerah Kota Pekanbaru peneliti mendapatkan keterangan untuk menjawab penelitian ini, dari segi sumber daya manusia Badan Kepegawaian Daerah Kota Pekanbaru telah memiliki pegawai yang langsung terjun didalam bidang-bidang tertentuyang nantinya akan menjalankan sistem aplikasi pelayanan kepegawaian (SAPK Online) berdasarkan bidang masing-masing, disini semua jumlah pegawai yang bekerja menggunakan SAPK ini berjumlah 25 orang yang terdiri dari berbagai bidang.

Selanjutnya mengenai ketersediaan sumber daya finansial, seperti yang telah dijelaskan diatas sumber daya finansial sangat berperan penting dalam penerapan Sistem Aplikasi Pelayanan Kepegawaian (SAPK Online) di Badan Kepegawaian Daerah Kota Pekanbaru, dalam hal ini dana awal sangat dibutuhkan agar sebuah kebijakan dapat diterapkan sebaik mungkin untuk memenuhi kebutuhan fisik seperti penambahan perangkat keras, dana penyambungan jaringan internet seperti wifi dan LAN serta penambahan tegangan arus listrik.

Dasar Hukum yang mendasari kebijakan penerapan e-Governmentmelalui SAPK Online diBadan Kepegawaian Daerah Kota Pekanbaru tahun 2008 adalah dimulai dari UUNo.23 Tahun 2014 tentang Pemerintahan Daerahyang mengatur pelimpahan wewenang seluas-luasnya dari pusat kepada daerah untuk mengembangkan potensi daerahnya masing-masing.

Dalam kebijakan penerapane-Government melalui SAPK Online diBadan Kepegawaian DaerahKota Pekanbaru dasar hukum lainnya yaitu Instruksi Presiden No. 3 Tahun 2003 tentang kebijakan dan Strategi Nasional Pengembangane-Government. Dasar hukum selanjutnya, Berdasarkan Undang-Undang Nomor 5 Tahun 2014 tentang pokok-pokok kepegawaian Aparatur Sipil Negara (ASN) menyatakan perlunya penyelenggaraan dan pemeliharaan Informasi Kepegawaian. Untuk mendukung kebijaksanaan tersebut, dipandang perlu dibangun dan dikembangan SistemAplikasi Pelayanan Kepegawaian(SAPK Online) sebagai penyempurna system sebelumnya yaitu SIMPEG, kebijakan ini dilaksanakan sesuai denganUndang-Undang Republik Indonesia Nomor11 Tahun 2008 tentang informasi dan transaksi elektronik dan seiring dikeluarkannya peraturan BKN NO.20 Tahun 2008 tentang pedoman pemanfaatan SAPK yang dalam perkembangannya dikelurkan pula peraturan Kepala Badan Kepegawaian Negara Nomor 18 Tahun 2010 tentang Prosedur Penetapan Nomor Identitas Pegawai Negeri Sipil,Kenaikan Pangkat, Pemberhentian dan Pemberian Pensiun Pegawai Negeri Sipil, dan Perpindahan Antar Instansi Berbasis Sistem Aplikasi Pelayanan Kepegawaian On-Line (SAPK On-Line).

Berdasarkan pemaparan diatas,bahwa ketersediaan dasar hukum yang dijadikan acuan untuk membangun SAPK di Badan Kepegawaian DaerahKota Pekanbaru cukup memadai, hal ini disebabkan adanya peraturan-peraturan yang mendukung dalam pembangunan dan pengembangan SAPK diBadanKepegawaianDaerahKota Pekanbarusudah tersedia secara rinci, namun dalam beberapa peraturan tersebut tidak adanya sanksidan reward, dengan demikian, bagisetiap daerah tidakwajibkanuntuk membangunSAPK. Peraturan-peraturan tersebut hanya bersifa timbauan bagi setiap pemerintah daerah.Dengan demikian dapat dilihat dasar hukum dalam kebijakan penerapan e-Government melalui 
SAPK diBadan Kepegawaian Daerah Kota Pekanbaru hanya ditingkat pusat saja tetapi peraturan ditingkat daerah belum ada, acuan hukum pengelolaan SAPK diBadan Kepegawaian Daerah Kota Pekanbaru masih mengacu kepada instruksi presiden Nomor 3 Tahun 2013 tentang kebijakan dan strategi nasional pembangunane-Government dan peraturan Kepala Badan Kepegawaian Negara Nomor 18 Tahun 2010 tentang Prosedur Penetapan Nomor Identitas Pegawai Negeri Sipil, Kenaikan Pangkat, Pemberhentian dan Pemberian Pensiun Pegawai Negeri Sipil, dan Perpindahan Antar Instansi Berbasis Sistem Aplikasi Pelayanan Kepegawaian On-Line (SAPK On-Line) serta belum terdapat peraturan secara teknis yang mendasari dalam pelaksanaan kebijakan penerapan e-Government melalui SAPK di Badan Kepegawaian Daerah Kota Pekanbaru.

c. Sosialisasi dan Diklat tentang SAPK online

sosialisasi sistem aplikasi pelayanan kepegawaian di BKD Kota Pekanbaru telah dilaksanakan, namun hanya baru satu kali dan lama pelaksanaan sosialisasi dan diklat selama 3 hari.

Yang dimaksud dengan capacity adalah adanya unsur kemampuan atau keberdayaan dari pemerintah setempat dalam mewujudkan penerapan SAPK Online. Ada tiga hal yang harus dimiliki oleh pemerintah sehubungan dengan elemen ini, yaitu:

a.Kualitas Sarana Teknologi dalam Kebijakan penerapan e Government melalui SAPK Online di BKD Kota Pekanbaru.

Dari hasil temuan dalam penelitian ini adalah ketersediaan sarana teknologi yang ada yang didapat dari hasil penelitian di Kantor Badan Kepegawaian Daerah Kota Pekanbaru : Pertama, jaringan komputer. Ketersediaan teknologi berupa jaringan komputer ini berupa jaringan Local Area Network (LAN) dan Wireless Fidelity (WiFi) yang berada di Badan Kepegawaian Daerah Kota Pekanbaru. Dengan adanya fasilitas jaringan tersebut maka sarana teknlogi yang mendukung dalam penerapan e-Government melalui di SAPK Online di Badan Kepegawaian Daerah Kota Pekanbaru dapat dikatakan cukup baik. Hal tersebut dapat terlihat dengan membangun fasilitas jaringan internet maupun intranet berupa WiFi dan jaringan LAN. Hal tersebut dapat dipahami karena dengan membangun fasilitas jaringan tersebut bertujuan untuk lebih memudahkan pendistribusian data kepegawaian dari masing-masing SKPD. Selain itu juga dapat digunakan sebagai media komunikasi antar SKPD dan Badan Kepegawaian Daerah Kota Pekanbaru. Tetapi dalam penggunaannya belum dapat dipergunakan secara maksimal oleh sebagian aparatur dikarenakan seringnya terjadi gangguan gagal koneksi sehingga proses login tidak bisa dilakukan. Hal yang sama juga kerap terjadi apa bila listrik padam dan melemahnya arus listrik diakibatnya banyaknya beban pemakaian komputer, wifi yang ada di kantor ini pun terkadang mengalami gangguan kecepatan yang tiba-tiba berkurang dikarenakan banyaknya user yang menggunakan.

b. Kesiapan Aparatur dalam melaksanakan kebijakan penerapan e Government melalui SAPK Online di BKD Kota Pekanbaru

Dalam hal ini kesiapan aparatur Negara sebagai aspek penting dalam menjalankan sebuah sistem baru harus lah menjadi pembahasan penting, sebab ketika aparatur Negara mampu menjalankan tugasnya dengan baik maka akan terwujud pula pelayanan yang memuaskan. Di dalam penelitian ini terdapat berbagai masalah mengenai kesiapan pegawai di Badan Kepegawaian Daerah Kota Pekanbaru, perkembangan teknologi yang semakin pesat memaksakan aparatur pemerintah untuk cakap terhadap teknologi masa kini.

Value

Penerapan SAPK, khususnya SAPK berbasis Online, juga memberikan manfaat dan keunggulan yang sangat besar dalam pelayanan kepegawaian, diantaranya adalah: pertama, memfasilitasi pelayanan kepegawaian yang terintegrasi mulai usulan dari instansi, proses penetapan persetujuan,penetapan SK di BKN sampai dengan penetapan SK oleh Instansi. SAPK berbasis Webini terkoneksi dengan aplikasi penghubung dengan stakeholder, aplikasi manajemen dokumen, penyempurnaan porta 1BKN, Executive 
Information System serta adanya helpdesk. Kedua, apabila terdapat penambahan maupun pengembangan aplikasi SAPK,maka cukup dilakukan disisi server di BKN Pusat. Ketiga, kemudahan akses dengan menggunakan aplikasi web browser. Keempat,disisi pengguna tidak membutuhkan ruang penyimpanan yang besar. Kelima,aplikasi berbasis Web terbuka bagi seluruh sistem operasi, seperti: Windows,Mac OS,Linux,dan sebagainya. Keenam, kemudahan akses SAPK,baik dengan menggunakan VPN maupun internet.

\section{KESIMPULAN}

Berdasarkan dari berbagai uraian yang telah penulis jelaskan sebelumnya, penulis mengambil kesimpulan bahwa Penerapan Sistem Aplikasi Pelayanan Kepegawaian (SAPKOnline) di Badan Kepegawaian Daerah Kota Pekanbaru sudah terlaksana. Namun pada dasarnya SDM atau pengguna sistem (User) yang ada di BKD Kota Pekanbaru belum mampu menggunakan dan memanfaatkan Sistem (SAPK Online) secara maksimal.

\section{DAFTAR PUSTAKA}

[1]. Budiati Ayuningsih, dkk, 2010. Ilmu Administrasi Negara Kontemporer. Graha Ilmu, Jakarta.

[2]. Furchan, A. 2004, Pengantar penelitian dan Pendidikan, Pustaka Pelajar, Yogyakarta.

[3]. Indrajit Richardus Eko, 2005, E-Goverment in action, Andi, Yogyakarta.

[4]. _ 2006, E-Government : Konsep Pelayanan Publik Berbasis Internet dan Teknologi Informasi, APTIKOM, Yogyakarta

[5]. Instruksi Presiden No. 3 Tahun 2003 Tentang strategi dan pengembangan E-Goverment.

[6]. Kadir Abdul, 2002, Pengenalan Sistem Informasi, Andi, Yogyakarta.

[7]. KMK.No. 85/RMK.02/2003 tentang modernisasi jangka menengah.

[8]. Keputusan MENPAN No. 8 Tahun 1993 tentang segala bentuk pelayanan umum yang dilaksanakan pemerintah pusat,di daerah dan lingkungan BUMN.

[9]. Kumorotomo, Wahyudi. 1996. Sistem Informasi Manajemen. Jogjakarta: Gajah Mada University .

[10]. Lubis , Hari dan Huseini Martani. 1998. Teori Organisasi, Pusat-pusat Antar Universitas Ilmu-ilmu Sosial. Jakarta : Univ Indonesia.

[11]. Moenir, H AS, Drs, Manajemen Pelayanan Umum Indonesia, Bumi aksara, Jakarta. 2008.

[12]. Moekijat. 1991. Pengantar Sistem Informasi Manajemen. Bandung: PT Remaja Rosdakarya

[13]. Mulyasa. 2002. Manajemen Berbasis Sekolah. Bandung : Remaja Resdakarya. 
[14]. Nugroho Eko, 2008, Sistem Informasi Manajemen, Andi, Yogyakarta.

[15]. Patilima, Hamid. 2005. Metode Penelitian Kualitatif. Bandung: Alfabeta

[16]. Peraturan BKN No. 2 Tahun 2008 tentang pedoman pemanfaatan SAPK.

[17]. Saputra, T. (2016). Kepuasan masyarakat terhadap penyelenggaraan pelayanan publik (studi kasus kantor Kecamatan Tambang Kabupaten Kampar). Jurnal Perspektif Pembiayaan dan Pembangunan Daerah, 4(2), 89-100.

[18]. Siagian, Sondang P. 2002. Manajemen Sumber Daya Manusia. Bandung : Pustaka Setia

[19]. Sukmadinata, 2006, Metode Penelitian Administrasi, Alfabeda, Bandung.

[20]. Safroni, M. Ladzi, 2012. Manajemen dan Reformasi Pelayanan Publik”dalam Konteks Birokrasi Indonesia. Aditya Media, Malang.

[21]. UU Nomor 5 Tahun 2014 tentang Aparatur Sipil Negara.

[22]. Wahab, Solichin Abdul. 2001. Analisis Kebijakan Publik. Jakarta : Gramedia.

[23]. Puspita, Denok. 2011. "Efektivitas Penerapan Sistem Informasi Administrasi Kependudukan di Dinas Kependudukan dan Catatan Sipil Surabaya". Jurnal Pendidikan Administrasi Perkantoran unesa. Vol 3, no. 4

[24]. http://ejournal.unesa.ac.id/index.php/jpap rticle/view/54278.Diakses pada 3 Maret 2016.

[25]. Nugroho, Eko, Dr, Ir, Sistem Informasi Manajemen, Andi Offset, 2008

[26]. Sinambela , Lijan Poltak, dkk. Reformasi Pelayanan Publik, teori, kebijakan dan implementasi. Jakarta : Bumi Aksara, 2006 